\title{
Physicochemical properties analysis of bamboo salt on chicken emulsion sausage
}

\author{
Sol-Hee Lee, Gye-Woong Kim* and Hack-Youn Kim* \\ Department of Animal Resources Science, Kongju National University, Yesan 32439, Korea
}

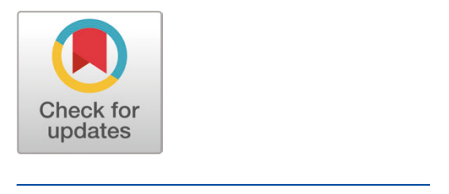

Received: Nov 1, 2019

Revised: Dec 3, 2019

Accepted: Dec 11, 2019

${ }^{*}$ Corresponding author Hack-Youn Kim

Department of Animal Resources Science, Kongju National University,

Yesan 32439, Korea.

Tel: +82-41-330-1241

E-mail: kimhy@kongju.ac.kr

Gye-Woong Kim

Department of Animal Resources

Science, Kongju National University,

Yesan 32439, Korea.

Tel: +82-41-330-1245

E-mail: kimgoong@kongju.ac.kr

Copyright $\odot 2020$ Korean Society of Animal Sciences and Technology.

This is an Open Access article distributed under the terms of the Creative Commons Attribution Non-Commercial License (http:// creativecommons.org/licenses/by$\mathrm{nc} / 4.0 /$ ) which permits unrestricted non-commercial use, distribution, and reproduction in any medium, provided the original work is properly cited.

ORCID

Sol-Hee Lee

https://orcid.org/0000-0003-1124-7095 Gye-Woong Kim

https://orcid.org/0000-0001-7325-9898

Hack-Youn Kim

https://orcid.org/0000-0001-5303-4595

Competing interests

No potential conflict of interest relevant to this article was reported.

\section{Abstract}

Quality characteristics of chicken emulsion sausage manufactured with various levels of $\mathrm{NaCl}$ and 9 times heated bamboo salt $(0.3 \%, 0.6 \%, 0.9 \%$, and $1.2 \%$ respectively) were examined. The $\mathrm{pH}$ value of chicken emulsion sausage was increase tendency with increasing amount of bamboo salt, on the contrary in case of $\mathrm{NaCl}$ sample were decrease tendency with increasing amount of $\mathrm{NaCl}$. Both before and after heating, redness of chicken emulsion sausage with bamboo salt treatments were upward trend with increasing amount of bamboo salt. water holding capacity $(\mathrm{WHC})$ of $1.2 \% \mathrm{NaCl}$ sample was significantly higher than $0.3 \%-0.9 \%(p$ $<0.05)$, but $0.9 \%, 1.2 \%$ bamboo salt samples were significantly higher than $0.3,0.6 \%(p<$ 0.05 ). Water loss of $1.2 \% \mathrm{NaCl}$ and $0.9 \%$ bamboo salt samples were significantly lower than other treatment $(p<0.05)$. Protein solubility values significantly increased amount of bamboo salt and $\mathrm{NaCl}(p<0.05)$, and samples of $0.9 \% \mathrm{NaCl}$ and $0.6 \%$ bamboo salt values show similar values. Cooking yield of samples were increased tendency with increasing amount of $\mathrm{NaCl}$ and bamboo salt. Also viscosity values of sample containing $1.2 \%$ bamboo salt sample showed higher viscosity than other treatments. These results show that containing $1.2 \%$ $\mathrm{NaCl}$ chicken emulsion sausage and $0.9 \%$ bamboo salt chicken emulsion sausage were similar physicochemical properties. Therefore, bamboo salt is suitable for manufacturing chicken emulsion sausage.

Keywords: Bamboo salt, Chicken, Low-salt, NaCl, Sausage

\section{INTRODUCTION}

According to the Korea National Health and Nutrition Examination Survey, the average daily consumption of sodium is showing a continuously decreasing trend with 4,027 $\mathrm{mg}$ in $2014,3,890 \mathrm{mg}$ in $2015,3,890 \mathrm{mg}$ in 2016, and 3,669 $\mathrm{mg}$ in 2017. However, the consumption level remains high, being almost two-fold higher than 2,000 mg, which is the recommended amount by the World Health Organization [1]. According to the survey by Nam [2], more than $50 \%$ of the respondents recognized the issue of over-consumption of sodium. Sodium over-consumption has been reported to induce disorders such as obesity, hypertension, strokes, diabetes, and cardiovascular diseases [3].

In the right amount, $\mathrm{NaCl}$ plays an important role in maintaining the homeostasis of our body, such as providing nutrients and removing waste from the cells, regulating blood salinity and pressure, and maintaining body moisture [4]. $\mathrm{NaCl}$ consumed through food significantly affects food taste, flavor, and 
Funding sources

This work was supported by the research grant of the Kongju National University in 2019.

Acknowledgements

Not applicable.

\section{Availability of data and material Upon reasonable request, the datasets of this study can be available from the corresponding author. \\ Authors' contributions \\ Conceptualization: Lee SH. \\ Data curation: Lee SH, Kim HY. \\ Formal analysis: Lee SH, Kim GY. \\ Methodology: Kim HY, Kim GY. \\ Software: Lee SH, Kim HY. \\ Validation: Lee $\mathrm{SH}$. \\ Investigation: Lee SH, Kim HY, Kim GY. \\ Writing - original draft: Lee SH. \\ Writing - review \& editing: Lee SH, Kim HY, Kim GY.}

Ethics approval and consent to participate This article does not require IRB/IACUC approval because there are no human and animal participants. texture [5]. However, excessive intake of $\mathrm{NaCl}$ was brought up to harmful effect like hypertension, stroke, and kidney function decline [6]. Therefore, various studies are currently being conducted to decrease the salt concentration in paste, salted seafood, and kimchi industries [7]. These studies are mainly focusing on replacing $\mathrm{NaCl}$ with $\mathrm{KCl}, \mathrm{MgCl}_{2}, \mathrm{CaCl}_{2}$, or natural substances [8].

In sausage production, it is difficult to extract optimum salt-soluble proteins below a certain level of salt concentration, leading to reduced emulsifying capacity, which negatively affects sausage taste and texture. Further, extraction of salt-soluble protein is greatly affected by $\mathrm{pH}$ change [9]. The lowest values of water holding capacity (WHC) in meat are observed around the isoelectric point at $\mathrm{pH}$ 5.2-5.4. Away from the isoelectric point, the cations and anions become more unbalanced, allowing water molecules to be incorporated [10] and increasing the WHC. Thus, the alkaline salts can be used to manufacture low-salt-processed meat products [11].

The alkaline salts include malt salt, yellow mud salt, baked natural sea salt, and bamboo salt. The bamboo salt is produced by placing natural sea salt in bamboo containers, covered and sealed with yellow mud, and baked at around $1,000^{\circ} \mathrm{C}$ for 1-9 times [12]. In bamboo salt products baked for several times, the calcium and potassium contents increased, making the final salt alkaline [13]. The bamboo salt exhibits antioxidant activity in food and contributes to reducing the acidification in the body, which causes various diseases [14]. Kim et al. [15] reported bamboo salt to be effective in inhibiting dental plaque, reducing gum disease, and reducing bacteria in the oral cavity. Bamboo salt products have been developed and are being used as soybean paste, red pepper paste, soy sauce, soap, and cosmetics [16]. However, using bamboo salt for low-salt meat product was not been studied, and studies are required to bamboo salt on meat product. Therefore, this study aimed to compare and analyze chicken breast emulsion sausage with bamboo salt and $\mathrm{NaCl}$.

\section{MATERIALS AND METHODS}

\section{Preparation of $\mathrm{NaCl}$ and bamboo salt on chicken emulsion sausage}

The chicken emulsion sausage used in this experiment were manufactured using chicken breast (ShinwooFS, Chungnam, Korea) 24 hours after butcher. The breast meat and pork lard ground using a grainder with $3 \mathrm{~mm}$ plates (PA-82, Mainca, Barcelona, Spain). The chicken breast meat, pork back fat, ice emulsified in a bowl cutter (K-30, Talsa, Valencia, Spain). 8 Samples made with 9 times heated bamboo salt (Kaeam food, Jeonbuk, Korea) and $\mathrm{NaCl}$ added $0.3 \%, 0.6 \%, 0.9 \%$, and $1.2 \%$ respectively. The emulsion was filled with the stuffer (EM-12, Mainca, Barcellona, Spain) and heated for $40 \mathrm{~min}$ in the $80^{\circ} \mathrm{C}$ chamber (10.10ESI/SK, Alto Shaam, WI, USA). After heating, it was cooled at $10^{\circ} \mathrm{C}$ for $20 \mathrm{~min}$. The sausages manufactured were kept at $4{ }^{\circ} \mathrm{C}$ and tested. The bamboo salt was contained $37.4 \% \mathrm{Na}, 57.5 \% \mathrm{Cl}, 0.55 \% \mathrm{~K}, 0.5 \% \mathrm{Ca}, 0.52 \% \mathrm{Mg}, 0.0093 \% \mathrm{Fe}, 0.0026 \% \mathrm{Mn}$, $0.00085 \% \mathrm{Zn}, 0.56 \% \mathrm{Si}$, and $0.86 \% \mathrm{~S}$. The color of bamboo salt was CIE L*: 84.2, CIE a*: 2.5, CIE $b^{*}: 15.3$

$\mathrm{pH}$

$\mathrm{pH}$ is measured mixing $4 \mathrm{~g}$ of sample and $16 \mathrm{ml}$ of distilled water using anura turrax (HMZ-20DN, Pooglim Tech, Seongnam, Korea). Homogenizing for one min at 14,336 $\mathrm{xg}$ and measuring a glass electrode $\mathrm{pH}$ meter (Model S220, Mettler-Twoldo, Schwitzer, Switzerland).

\section{Instrumental color}

Before and after heating the chicken emulsion sausage were measured and recorded. Color value were display the lightness $(\mathrm{CIE} \mathrm{L})$, the redness $\left(\mathrm{CIE} \mathrm{a}^{*}\right)$ values and the yellowness value $\left(\mathrm{CIE}^{*}\right)$ using the colorimetric (CR-10, Minolta, Tokyo, Japan). The color calibrated with a white plate (CIE 


\section{$L^{*}:+97.83$, CIE a*: -0.43, CIE b* $\left.{ }^{*}+1.98\right)$.}

\section{Protein solubility}

Protein solubility of chicken emulsion sausage was determined following Farouk and Swan [17]. The total protein solubility was added $20 \mathrm{~mL}$ of buffer $(1.1 \mathrm{M}$ potassium iodide in $0.1 \mathrm{M}$ potassium phosphate buffer) in a $2 \mathrm{~g}$ sample. The sarcoplasmic protein solubility measured mixture added to the $2 \mathrm{~g}$ raw sample with buffer ( $0.025 \mathrm{M}$ potassium phosphate). Each sample were homogenized using homogenizer (AM-5, Nihonseiki, Kaissa, Tokyo, Japan) at 8,064 $\mathrm{xg}$ for $2 \mathrm{~min}$. After homogenized, keep for 16 hour at $4^{\circ} \mathrm{C}$. Two sample filter using filter paper. The sample supernatant was measured by absorbance of $540 \mathrm{~nm}$ using multi-mode microplate reader (Spectra Max iD3, Molecular devices, CA, USA). Myofibrillar protein solubility were calculated by difference between total and sarcoplasmic protein solubility.

\section{Water-holding capacity (WHC)}

The experiment was conducted using centrifugation to measure the water-holding capacity of chicken emulsion sausage. Put in a cotton under the conical tube and seal the heated sample in a filter paper. Weighed before and after turning to the machine (temperature: $4^{\circ} \mathrm{C}, 224 \times \mathrm{g}$, time: 10 $\mathrm{min})$. The moisture content was measured by the drying oven method at $105^{\circ} \mathrm{C}$ [18].

$$
\text { WHC }(\%)=\frac{\mathrm{A}-\mathrm{B}}{\mathrm{A}} \times 100
$$

$\mathrm{A}=($ Weight before centrifuge $(\mathrm{g}) \times$ Water content $(\%)) / 100$

$\mathrm{B}=($ Weight before centrifuge - Weight after centrifuge $)$

\section{Emulsion stability}

A 15 mesh sieve $(4 \times 4 \mathrm{~mm}$ was placed in the under of a graduated glass tube and filled meat emulsion. Chicken emulsion sausage were cooked at $80^{\circ} \mathrm{C}$ for 40 min using chamber $(10.10 \mathrm{ESI} / \mathrm{SK}$, Alto Shaam, WI, USA). After cooling to approximately $4 \pm 1^{\circ} \mathrm{C}$ for $20 \mathrm{~min}$. After cooling, The layer of water and fat were measured and calculated.

$$
\begin{aligned}
& \text { Water exudation }=\frac{\text { The water layer }(\mathrm{mL})}{\text { Raw meat better weight }(\mathrm{g})} \times 100 \\
& \text { Fat exudation }(\%)=\frac{\text { The fat layer }(\mathrm{mL})}{\text { Raw meat better weight }(\mathrm{g})} \times 100
\end{aligned}
$$

\section{Cooking yield}

The weight before and after heating of the chicken emulsion sausage heated to $80^{\circ} \mathrm{C}$ for 40 min was recorded. Cooking yield was calculated. The following formulation is to calculate the cooking yield.

$$
\text { Cooking yield }(\%)=\frac{\text { Weight after cooking }(\mathrm{g})}{\text { Weight before cooking }(\mathrm{g})} \times 100
$$

Texture profile analysis (TPA)

TPA of the chicken emulsion sausage were heated for $40 \mathrm{~min}$ in the $80^{\circ} \mathrm{C}$ chamber $(10.10 \mathrm{ESI} / \mathrm{SK}$, Alto Shaam Co., WI, USA) and cooled for $20 \mathrm{~min}$ at $10^{\circ} \mathrm{C}$. Cooked sausage size of $\varnothing 2.5 \times 2.0 \mathrm{~cm}$ 
(height) was measured using Texture Analyzer (TA 1, Lloyd Co., FL, USA). The analysis condition are set to pre-test speed $2.0 \mathrm{~mm} / \mathrm{s}$, post-test speed $5.0 \mathrm{~mm} / \mathrm{s}$, maximum load $2 \mathrm{~kg}$, head speed 2.0 $\mathrm{mm} / \mathrm{s}$, distance $8.0 \mathrm{~mm}$, force $5 \mathrm{~g}$ equipped with $25 \mathrm{~mm}$ cylinder probe.

\section{Apparent viscosity}

The viscosity of the chicken emulsion sausage with $\mathrm{NaCl}$ and bamboo salt were investigated at $20 \pm$ $1^{\circ} \mathrm{C}$ using a rotational viscometer (MerlinVR, Rheosys, USA) equipped with $30 \mathrm{~mm}$ parallel plate $2.0 \mathrm{~mm}$ gap at $25^{\circ} \mathrm{C}$ under a shear rate of $4.48 \times \mathrm{g}$.

\section{Statistical analysis}

Conduct an experiment were evaluation at least 3 times under each condition. After experiment, results were expressed mean value and standard deviation using SAS (version 9.3 for window, SAS Institue Inc., NC, USA) and verified significant difference with ANOVA, Duncan's multiple range test.

\section{RESULTS AND DISCUSSION}

pH, color

Table 1 indicates the results for the $\mathrm{pH}$ and the color of chicken emulsion sausage as a function to the amount of added $\mathrm{NaCl}$ and bamboo salt, respectively. The treatment group with added bamboo salt before and after cooking showed significantly higher $\mathrm{pH}$ values compared to the control group with $\mathrm{NaCl}(p<0.05)$. The $\mathrm{pH}$ showed an increasing trend with increasing the amount of bamboo salt. This could be the result of acidic $\mathrm{pH}$ of $\mathrm{NaCl}$ with $\mathrm{pH} 5.4$ and alkaline $\mathrm{pH}$ of bamboo salt with $\mathrm{pH}$ 9.11. Research results of Choi et al. [19] also showed the highest $\mathrm{pH}$ after cooking meat with bamboo salt compared to other groups using various types of salt, which is in agreement with this study. Kim et al. [20] reported that the increased addition bamboo salt of 9 times heated led to an increase in $\mathrm{pH}$, which is also in agreement with this study.

The color before cooking in food products showed an intensification trend of lightness with increased bamboo salt, which can be due to the high lightness of bamboo salt with 84.2. The explanation of the redness color intensification before and after cooking may be related to the formation of nitroso-myoglobin from bonding of nitrite and myoglobin in the bamboo salt [21]. There was no significant difference in lightness, redness color, and yellowness for $\mathrm{NaCl}$ addition before cooking, but the redness color intensified after cooking. In the study by Park et al. [22] on the redness of sausage with $\mathrm{NaCl}$ addition reported that increased $\mathrm{NaCl}$ leads to an intensification in the redness,

Table 1. $\mathrm{pH}$, color of chicken-breast sausage formulated with various levels of $\mathrm{NaCl}$ and bamboo salt

\begin{tabular}{|c|c|c|c|c|c|c|c|c|c|c|}
\hline \multicolumn{3}{|c|}{ Traits } & \multicolumn{4}{|c|}{$\mathrm{NaCl}(\%)$} & \multicolumn{4}{|c|}{ Bamboo salt (\%) } \\
\hline & Iralts & & 0.3 & 0.6 & 0.9 & 1.2 & 0.3 & 0.6 & 0.9 & 1.2 \\
\hline \multirow[t]{2}{*}{$\mathrm{pH}$} & & Uncooked & $5.73 \pm 0.02^{d}$ & $5.68 \pm 0.02^{e}$ & $5.68 \pm 0.01^{\mathrm{e}}$ & $5.65 \pm 0.02^{\mathrm{e}}$ & $5.77 \pm 0.01^{\mathrm{c}}$ & $5.90 \pm 0.02^{b}$ & $5.93 \pm 0.02^{b}$ & $5.94 \pm 0.09^{a}$ \\
\hline & & Cooked & $6.10 \pm 0.04^{d}$ & $5.87 \pm 0.02^{\mathrm{e}}$ & $5.87 \pm 0.03^{\mathrm{e}}$ & $5.85 \pm 0.16^{\mathrm{e}}$ & $5.95 \pm 0.04^{c}$ & $6.05 \pm 0.03^{b}$ & $6.08 \pm 0.02^{\mathrm{a}}$ & $6.09 \pm 0.01^{a}$ \\
\hline \multirow[t]{6}{*}{ Color } & Uncooked & $\mathrm{CIE} \mathrm{L*}$ & $70.68 \pm 1.02^{\mathrm{a}}$ & $68.86 \pm 0.84^{\mathrm{bc}}$ & $68.86 \pm 0.25^{\mathrm{bc}}$ & $68.70 \pm 0.47^{\text {bod }}$ & $69.20 \pm 0.25^{b}$ & $67.76 \pm 0.53^{d}$ & $69.20 \pm 0.81^{\text {bod }}$ & $72.8 \pm 0.57^{d}$ \\
\hline & & $\mathrm{CIE} \mathrm{a}^{*}$ & $3.77 \pm 0.12^{b}$ & $3.73 \pm 0.15^{b}$ & $3.67 \pm 0.09^{b c}$ & $3.62 \pm 0.28^{\mathrm{bc}}$ & $3.45 \pm 0.12^{c}$ & $3.55 \pm 0.05^{\mathrm{bc}}$ & $3.77 \pm 0.09^{b}$ & $4.32 \pm 0.12^{\mathrm{a}}$ \\
\hline & & $\mathrm{CIE} b^{*}$ & $15.4 \pm 0.34^{b c}$ & $15.9 \pm 0.40^{c}$ & $15.6 \pm 0.12^{\mathrm{bc}}$ & $15.5 \pm 0.17^{\mathrm{bc}}$ & $16.5 \pm 0.45^{\mathrm{a}}$ & $15.6 \pm 0.37^{\mathrm{bc}}$ & $15.9 \pm 0.31^{b}$ & $15.2 \pm 0.22^{c}$ \\
\hline & Cooked & CIE L* & $78.9 \pm 0.40^{\mathrm{a}}$ & $78.5 \pm 0.45^{\mathrm{ab}}$ & $78.0 \pm 0.09^{\mathrm{ab}}$ & $77.6 \pm 1.04^{b}$ & $79.0 \pm 0.80^{\mathrm{a}}$ & $77.8 \pm 1.07^{b}$ & $78.0 \pm 0.28^{\mathrm{ab}}$ & $78.0 \pm 0.53^{\mathrm{ab}}$ \\
\hline & & $\mathrm{CIE} \mathrm{a}^{*}$ & $3.55 \pm 0.1^{c}$ & $3.65 \pm 0.19^{\mathrm{bc}}$ & $3.72 \pm 0.09^{\mathrm{bc}}$ & $4.00 \pm 0.21^{\mathrm{ab}}$ & $3.67 \pm 0.09^{b c}$ & $4.00 \pm 0.21^{\mathrm{ab}}$ & $4.20 \pm 0.52^{\mathrm{a}}$ & $4.17 \pm 0.25^{\mathrm{a}}$ \\
\hline & & CIE $b^{*}$ & $14.5 \pm 0.17^{b}$ & $14.3 \pm 0.18^{\mathrm{bc}}$ & $14.9 \pm 0.39^{\mathrm{a}}$ & $14.0 \pm 0.21^{\mathrm{cd}}$ & $13.8 \pm 0.17^{d}$ & $13.4 \pm 0.34^{\mathrm{e}}$ & $13.3 \pm 0.35^{\mathrm{e}}$ & $13.3 \pm 0.19^{\mathrm{e}}$ \\
\hline
\end{tabular}

All values are mean \pm SD.

${ }^{\mathrm{a}-\mathrm{e}}$ Mean in the all treatment with different letters are significantly different $(p<0.05)$. 
which is in agreement with this study.

\section{WHC, emulsion stability, protein solubility}

WHC and emulsion stability of chicken emulsion sausage as a function to the amount of added $\mathrm{NaCl}$ and bamboo salt addition is shown Table 2. The WHC is important in emulsion since it determines the maintenance of the matrix structure of moisture, protein, and fat during salt addition [23]. The WHC showed an increasing trend with increasing $\mathrm{NaCl}$ and bamboo salt content, and the group with $1.2 \%$ bamboo salt showed a significantly higher WHC compared to all other treatment groups $(p<0.05)$. This is due to an increased WHC in $\mathrm{pH}$ further from the isoelectric point ( $\mathrm{pH}$ 5.2-5.6) [20]. The $0.9 \%$ and $1.2 \%$ bamboo salt treatment groups had higher $\mathrm{pH}$ values compared to the other treatment groups. Similar to the results of this study, Debut [24] reported a decreased $\mathrm{pH}$ value leading to a decreased WHC value in chicken meat.

The results of chicken emulsion stability indicated that the $0.3 \% \mathrm{NaCl}$ treatment group had significantly higher moisture contents compared to all the other treatment groups $(p<0.05)$, and the fat contents showed a decreasing trend with increased addition of both $\mathrm{NaCl}$ and bamboo salt. An explanation might be the reduced moisture contents with increased WHC due to strengthened cross-linked bonds between protein and water molecules. Kim et al. [20] studied sausages added with $\mathrm{NaCl}$, alkaline salt, bamboo salt baked 2 and 9 times, and the results showed the treatment group with bamboo salt baked 9 times with high $\mathrm{pH}$ had the lowest moisture content, similar to the results of this study. This suggests that the use of bamboo salt with high $\mathrm{pH}$ can increase the WHC of meat products to produce food with excellent texture.

The protein solubility for $\mathrm{NaCl}$ and bamboo salt addition is shown in Table 3. The salt-soluble proteins affect the WHC, texture, and preference of sausage emulsion, and thus, have important effects on the final product [25]. The solubility of sarcoplasmic protein, myofiblilar protein, and total protein showed an increasing trend with increased $\mathrm{NaCl}$ and bamboo salt content, and the protein

Table 2. WHC and emulsion stability of chicken-breast sausage formulated with various levels of $\mathrm{NaCl}$ and bamboo salt

\begin{tabular}{|c|c|c|c|c|c|c|c|c|c|}
\hline \multirow{2}{*}{\multicolumn{2}{|c|}{ Traits }} & \multicolumn{4}{|c|}{$\mathrm{NaCl}(\%)$} & \multicolumn{4}{|c|}{ Bamboo salt (\%) } \\
\hline & & 0.3 & 0.6 & 0.9 & 1.2 & 0.3 & 0.6 & 0.9 & 1.2 \\
\hline WHC (\%) & & $67.88 \pm 0.74^{b}$ & $69.96 \pm 1.35^{b}$ & $70.55 \pm 1.90^{b}$ & $71.40 \pm 0.43^{\mathrm{a}}$ & $69.28 \pm 1.28^{b}$ & $68.41 \pm 0.25^{b}$ & $76.56 \pm 0.41^{a}$ & $81.37 \pm 1.30^{\mathrm{a}}$ \\
\hline \multirow[t]{2}{*}{$\begin{array}{l}\text { Emulsion } \\
\text { stability (\%) }\end{array}$} & $\begin{array}{l}\text { Water loss } \\
(\%)\end{array}$ & $12.45 \pm 0.87^{\mathrm{a}}$ & $7.24 \pm 0.56^{b}$ & $6.22 \pm 0.50^{b}$ & $5.30 \pm 0.29^{b}$ & $8.35 \pm 0.62^{b}$ & $6.92 \pm 0.15^{b}$ & $5.46 \pm 0.29^{b}$ & $4.64 \pm 0.34^{b}$ \\
\hline & $\begin{array}{l}\text { Fat loss } \\
(\%)\end{array}$ & $0.47 \pm 0.19^{\mathrm{a}}$ & $0.26 \pm 0.13^{\mathrm{ab}}$ & $0.12 \pm 0.12^{\text {bcd }}$ & $0.04 \pm 0.03^{d}$ & $0.38 \pm 0.10^{\mathrm{ab}}$ & $0.20 \pm 0.06^{\text {bcd }}$ & $0.11 \pm 0.10^{\text {cd }}$ & $0.03 \pm 0.02^{\text {cd }}$ \\
\hline
\end{tabular}

All values are mean $\pm S D$.

${ }^{a-d}$ Mean in the all treatment with different letters are significantly different $(p<0.05)$.

WHC, water holding capacity.

Table 3. Protein solubility of chicken-breast sausage formulated with various levels of $\mathrm{NaCl}$ and bamboo salt

\begin{tabular}{|c|c|c|c|c|c|c|c|c|}
\hline \multirow{2}{*}{ Traits } & \multicolumn{4}{|c|}{$\mathrm{NaCl}(\%)$} & \multicolumn{4}{|c|}{ Bamboo salt (\%) } \\
\hline & 0.3 & 0.6 & 0.9 & 1.2 & 0.3 & 0.6 & 0.9 & 1.2 \\
\hline Total protein $(\mu \mathrm{g} / \mu \mathrm{L})$ & $\begin{array}{c}1,053.66 \pm \\
0.49^{f}\end{array}$ & $\begin{array}{c}1,063.18 \pm \\
0.49^{\mathrm{e}}\end{array}$ & $\begin{array}{c}1,248.70 \pm \\
0.49^{c}\end{array}$ & $\begin{array}{c}1,249.56 \pm \\
0.49^{c}\end{array}$ & $\begin{array}{c}1,009.52 \pm \\
0.99^{9}\end{array}$ & $\begin{array}{c}1,185.51 \pm \\
0.49^{d}\end{array}$ & $\begin{array}{c}1,344.49 \pm \\
0.49^{b}\end{array}$ & $\begin{array}{c}1,395.26 \pm \\
0.86^{\mathrm{a}}\end{array}$ \\
\hline Myofibilla protein $(\mu \mathrm{g} / \mu \mathrm{L})$ & $\begin{array}{c}807.27 \pm \\
0.49^{g}\end{array}$ & $\begin{array}{c}836.12 \pm \\
0.86^{f}\end{array}$ & $\begin{array}{c}1,018.75 \pm \\
0.86^{d}\end{array}$ & $\begin{array}{c}1,028.27 \pm \\
0.86^{c}\end{array}$ & $\begin{array}{c}785.92 \\
1.32^{h}\end{array}$ & $\begin{array}{c}961.91 \pm \\
0.99^{\mathrm{e}}\end{array}$ & $\begin{array}{c}1,106.75 \pm \\
0.86^{b}\end{array}$ & $\begin{array}{c}1,151.47 \pm \\
0.99^{\mathrm{a}}\end{array}$ \\
\hline Sarcoplasmic protein $(\mu \mathrm{g} / \mu \mathrm{L})$ & $\begin{array}{c}246.39 \pm \\
0.50^{\mathrm{a}}\end{array}$ & $\begin{array}{c}227.06 \pm \\
0.50^{\mathrm{e}}\end{array}$ & $\begin{array}{c}229.95 \pm \\
0.49^{d}\end{array}$ & $\begin{array}{c}221.29 \pm \\
0.49^{9}\end{array}$ & $\begin{array}{c}223.60 \pm \\
0.39^{f}\end{array}$ & $\begin{array}{c}223.74 \pm \\
0.45^{f}\end{array}$ & $\begin{array}{c}237.74 \pm \\
0.45^{\mathrm{c}}\end{array}$ & $\begin{array}{c}243.80 \pm \\
0.49^{b}\end{array}$ \\
\hline
\end{tabular}

All values are mean $\pm \mathrm{SD}$.

${ }^{a-h}$ Mean in the all treatment with different letters are significantly different $(p<0.05)$. 
solubility of the $0.6 \%-1.2 \%$ bamboo salt treatment groups, with the exception of the $0.3 \%$ bamboo salt treatment group, showed higher values compared to the $\mathrm{NaCl}$ group. According to the report by Kenney and Hunt [26], the emulsion in the $4 \% \mathrm{NaCl}$ treatment group indicated the highest protein solubility among the 2 and $4 \% \mathrm{NaCl}$ treatment, similar to the results of this study. This suggests that the bamboo salt has outstanding emulsion capacity and can be used to produce low salt meat products since its alkaline $\mathrm{pH}$ increases the $\mathrm{WHC}$ and the protein solubility.

\section{Cooking yield, viscosity, and TPA}

Fig. 1 shows the cooking yield of the chicken emulsion sausage according to the amount of added $\mathrm{NaCl}$ and bamboo salt, indicating an increased trend of cooking yield with increased $\mathrm{NaCl}$ and bamboo salt contents. Compared to the 0.3 and $0.6 \% \mathrm{NaCl}$ treatment groups and the $0.3 \%$ bamboo salt treatment group, the $1.2 \%$ bamboo salt treatment group had a significantly higher cooking yield $(p<0.05)$. This could be due to an increased amount of extracted salt-soluble protein with increased salt addition, leading to stronger binding; the extracted salt-soluble protein increased the WHC, which in turn, increased the cooking yield. This is similar to the results of the study by Sikes et al. [27] that reported a decreased cooking yield at lower $\mathrm{NaCl}$ contents, where the binding capacity of emulsion increased with the bonding between moisture, fat, and protein, reducing the amount of water and oil separation [28].

The viscosity values of emulsion obtained with $\mathrm{NaCl}$ and bamboo salt respectively are shown in Fig. 2 . The results indicated that the $0.3 \% \mathrm{NaCl}$ has the lowest value and the $1.2 \%$ bamboo salt treatment group has the highest one. The emulsion treated with $0.9 \% \mathrm{NaCl}$ and $0.3 \%$ bamboo salt exhibited similar viscosity values. Also, the values of the $1.2 \% \mathrm{NaCl}$ and $0.6 \%$ bamboo salt groups were similar. Aktas and Genccelep [29] reported that the emulsion viscosity and stability are positively correlated, and the emulsion stability has an important role in the quality of meat products, thus viscosity being an important indicator for emulsion stability. Further, Zhao [30] reported that the increased emulsion viscosity lead to increase the score in sensory evaluation. Therefore, the emulsion with high viscosity can play an important role in the cooking yield, the $\mathrm{WHC}$, and the physical properties of manufactured products.

The texture properties directly affect the customer's choice, therefore, it is important to analyze the optimum values [31]. The results of the TPA measurements of the chicken breast sausage with added $\mathrm{NaCl}$ and bamboo salt are presented in Table 4. Hardness was similar between the $0.9 \%$

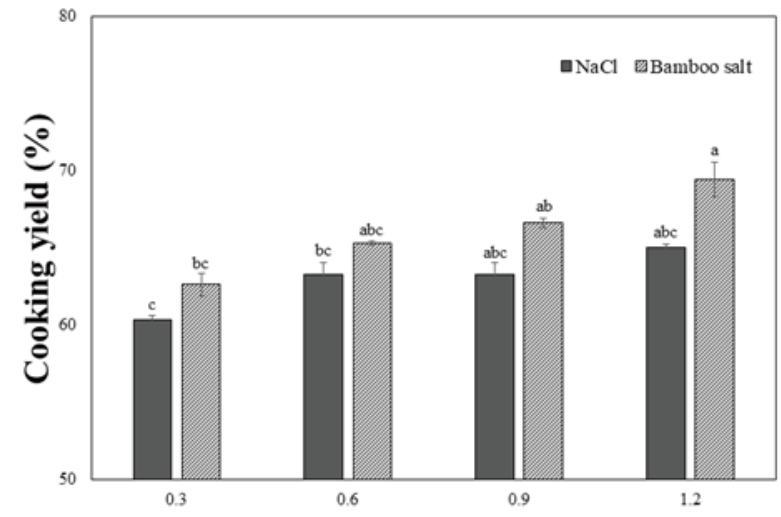

Fig. 1. Cooking yield of chicken-breast sausage formulated with various levels of $\mathrm{NaCl}$ and bamboo salt. ${ }^{a, b}$ Mean in the all treatment bars with different letters are significantly different $(p<0.05)$.

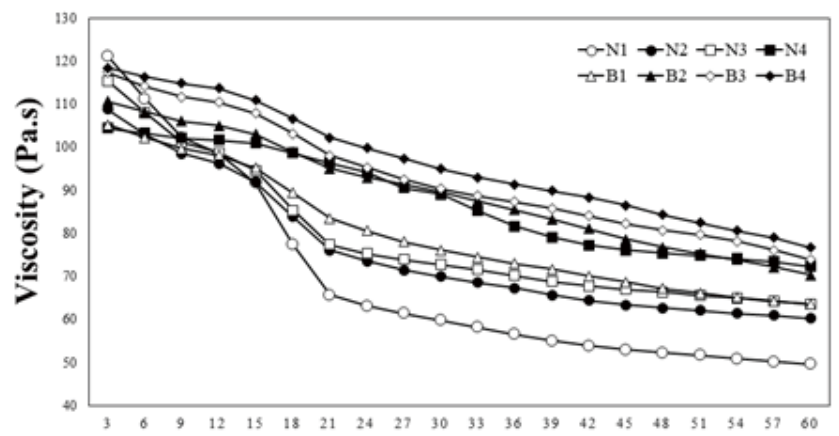

Fig. 2. Change of apparent viscosity on chicken-breast sausage formulated with various levels of $\mathrm{NaCl}$ and bamboo salt. $\mathrm{N} 1$, sausage with $0.3 \% \mathrm{NaCl}$; $\mathrm{N} 2$, sausage with $0.6 \% \mathrm{NaCl}$; N3, sausage with $0.9 \%$ $\mathrm{NaCl}$; $\mathrm{N}$, sausage with $1.2 \% \mathrm{NaCl}$; $\mathrm{B} 1$, sausage with $0.3 \%$ bamboo salt; $B 2$, sausage with $0.6 \%$ bamboo salt; $B 3$, sausage with $0.9 \%$ bamboo salt; $\mathrm{B} 4$, sausage with $1.2 \%$ bamboo salt. 
Table 4. Texture properties analysis of chicken-breast sausage formulated with various levels of $\mathrm{NaCl}$ and bamboo salt

\begin{tabular}{|c|c|c|c|c|c|c|c|c|}
\hline \multirow{2}{*}{ Traits } & \multicolumn{4}{|c|}{$\mathrm{NaCl}(\%)$} & \multicolumn{4}{|c|}{ Bamboo salt (\%) } \\
\hline & 0.3 & 0.6 & 0.9 & 1.2 & 0.3 & 0.6 & 0.9 & 1.2 \\
\hline Hardness (kgf) & $4.54 \pm 0.34^{d}$ & $5.44 \pm 0.35^{\mathrm{c}}$ & $5.86 \pm 0.30^{\mathrm{bc}}$ & $6.32 \pm 0.30^{\mathrm{a}}$ & $5.44 \pm 0.36^{c}$ & $5.84 \pm 0.37^{\mathrm{bc}}$ & $5.91 \pm 0.61^{\mathrm{ab}}$ & $6.34 \pm 0.44^{\mathrm{a}}$ \\
\hline Springness & $0.83 \pm 0.06^{a}$ & $0.79 \pm 0.06^{\mathrm{ab}}$ & $0.82 \pm 0.08^{\mathrm{a}}$ & $0.81 \pm 0.01^{\mathrm{ab}}$ & $0.75 \pm 0.11^{\mathrm{ab}}$ & $0.78 \pm 0.06^{\mathrm{ab}}$ & $0.82 \pm 0.06^{a}$ & $0.73 \pm 0.03^{b}$ \\
\hline Cohesiveness & $0.47 \pm 0.03^{\mathrm{ab}}$ & $0.50 \pm 0.08^{\mathrm{ab}}$ & $0.49 \pm 0.08^{\mathrm{ab}}$ & $0.50 \pm 0.04^{\mathrm{ab}}$ & $0.45 \pm 0.09^{b}$ & $0.51 \pm 0.05^{\mathrm{ab}}$ & $0.54 \pm 0.08^{\mathrm{a}}$ & $0.47 \pm 0.05^{\mathrm{ab}}$ \\
\hline Gumminess (kgf) & $2.16 \pm 0.18^{c}$ & $2.78 \pm 0.58^{\mathrm{ab}}$ & $2.91 \pm 0.49^{\mathrm{ab}}$ & $3.19 \pm 0.37^{\mathrm{a}}$ & $2.46 \pm 0.54^{\mathrm{bc}}$ & $3.01 \pm 0.48^{a}$ & $3.18 \pm 0.38^{\mathrm{a}}$ & $3.00 \pm 0.45^{\mathrm{a}}$ \\
\hline Chewiness (kgf) & $1.79 \pm 0.17^{c}$ & $2.22 \pm 0.58^{\mathrm{abc}}$ & $2.44 \pm 0.62^{\mathrm{ab}}$ & $2.59 \pm 0.33^{\mathrm{a}}$ & $1.90 \pm 0.62^{\mathrm{bc}}$ & $2.36 \pm 0.51^{\mathrm{ab}}$ & $2.63 \pm 0.46^{\mathrm{a}}$ & $2.22 \pm 0.41^{\mathrm{abc}}$ \\
\hline
\end{tabular}

All values are mean $\pm S D$

${ }^{a-c}$ Mean in the all treatment with different letters are significantly different $(p<0.05)$.

$\mathrm{NaCl}$ and $0.6 \%$ bamboo salt groups. This similarity could be due to the higher WHC in bamboo salt with alkaline $\mathrm{pH}$. Further, increased $\mathrm{NaCl}$ and bamboo salt contents led to increasing values of hardness, which is in agreement with the report by Ruusunen et al. [32] showing increasing hardness with increased addition of $\mathrm{NaCl}$ in a frankfurter.

\section{CONCLUSION}

These results of this research suggest that bamboo salt can be used as a low salt in chicken emulsion sausage. Added at $0.9 \%$ bamboo salt were similar $1.2 \% \mathrm{NaCl}$, the addition of $0.9 \%$ bamboo salt can enhance the low salt chicken emulsion sausage. Furthermore, bamboo salt on meat would probably result in better than those that use $\mathrm{NaCl}$.

\section{REFERENCES}

1. Korea Centers for Disease Control and Prevention [KCDC]. National health statistics at 2017. 2018. https://knhanes.cdc.go.kr/knhanes/sub04/sub04_03.do. Accessed 15 Jul 2019.

2. Nam HJ.The relationship between perception of hypertension and low sound diet practices. [Ph. D. dissertation]. Seoul, Korea: Myongij University; 2003.

3. Jeong SN. A study on the sodium intake and dietary performance in patients of general and low salt diet. [M.S. thesis]. Seoul, Korea: Yonsei University; 2009.

4. Fujino Y. Living science of table salt in human ecology.J East Asian Diet Life. 1999;9:230-44.

5. Gillette M. Flavor effects of sodium chloride. Food Technol. 1985;39:47-52.

6. De Wardener HE, Macgregor GA. Harmful effects of dietary salt in addition to hypertension. J Hum Hypertens. 2002;16:213-23.

7. Kim SJ. Production of low-salt kimchi and cases of sodium-reduction. Food Sci Ind. 2016;49:45-50.

8. Tremonte P, Gambacorta G, Pannella G, Trani A, Succi M, La Gatta L, et al. NaCl replacement with $\mathrm{KCl}$ affects lipolysis, microbiological and sensorial features of Soppressata molisana. Eur J Lipid Sci Technol. 2018;120:1700449.

9. de Moraes MC, Cunha RL. Gelation property and water holding capacity of heat-treated collagen at different temperature and $\mathrm{pH}$ values. Food Res Int. 2013;50:213-23.

10. Korea Meat Science Research Society. Meat science. Seoul, Korea: Sunjin Munhwasa; 2018. p. 169-73. https://book.naver.com/bookdb/book_detail.nhn?bid=13414739. Accessed 15 Jul 2019.

11. Kim GD, Hur SJ, Park TS, Jine SK. Quality characteristics of fat-reduced emulsion-type pork sausage by partial substitution of sodium chloride with calcium chloride, potassium chloride and magnesium chloride. LWT Food Sci Technol. 2018;89:140-7. 
12. Hwang IM, Yang JS, Kim SH, Jamila N, Khan N, Kim KS, et al. Elemental analysis of sea, rock, and bamboo salts by inductively coupled plasma-optical emission and mass spectrometry. J Anal Lett. 2016;49:2807-21.

13. Lee SJ. Sulfur compound and mineral generated during manufacture of bamboo salt. [M.S. thesis]. Mokpo, Korea: Mokpo University; 2012.

14. Zhao X, Jung OS, Park KY. 2012. Alkaline and antioxidant effects of bamboo salt. J Korean Soc Food Sci Nutr. 2012;41:1301-4.

15. Kim SH, Kang SY, Jung KK, Kim TG, Han HM, Rheu HM, Moon A. Characterization and anti-gastric ulcer activity of bamboo salt.J Food Hyg Saf. 1998;13:252-7.

16. Jeong MW, Jeong JK, Kim SJ, Park KY. Fermentation characteristics and increased functionality of doenjang prepared with bamboo salt. J Korean Soc Food Sci Nutr. 2013;42:1915-23.

17. Farouk MM, Wieliczko KJ. Optimum time for using chilled beef in gelled products. J Food Sci. 2003;68:164-7.

18. AOAC. Official methods of analysis. 15th ed. Washington DC: Association of Official Analytical Chemists; 1990.

19. Choi YS, Jeong TJ, Hwang KE, Song DH, Ham YK, Kim YB, et al. Effects of various salts on physicochemical properties and sensory characteristics of cured meat. Korean J Food Sci Anim Resour. 2016;36:152-8.

20. Kim HY, Lee ES, Jeong JY, Choi JH, Choi YS, Han DJ, et al. Effect of bamboo salt on the physicochemical properties of meat emulsion systems. Meat Sci. 2010;86:960-5.

21. Bozkurt H, Erkmen O. Effect of nitrate/nitrite on the quality of sausage (sucuk) during ripening and storage.J Sci Food Agric. 2004;84:279-86.

22. Park SY, Kim HY. Effects of $\mathrm{NaCl}$ concentration on physicochemical properties of pork emulsion.J Korean Soc Food Sci Nutr. 2016;45:551-6.

23. Huff-Lonergan E, Lonergan SM. Mechanisms of water-holding capacity of meat: the role of postmortem biochemical and structural changes. Meat Sci. 2005;71:194-204.

24. Debut M, Berri C, Baeza E, Sellier N, Arnould C, Guemene D, et al. Variation of chicken technological meat quality in relation to genotype and preslaughter stress conditions. Poult Sci. 2003;82:1829-38.

25. Kang GH, Han CY, Joo ST, Kim BC, Park GB. Effects of addition levels of sodium chloride on gel properties of surimi-like pork. Korean J Food Sci Anim Resour. 2006;26:20-7.

26. Kenney PB, Hunt MC. Effect of water and salt content on protein solubility and water retention of meat preblends. Meat Sci. 1990;27:173-80.

27. Sikes AL, Tobin AB, Tume RK. Use of high pressure to reduce cook loss and improve texture of low-salt beef sausage batters. Innov Food Sci Emerg Technol. 2009;10:405-12.

28. Whiting RC. Stability and gel strength of frankfurter batters made with reduced $\mathrm{NaCl}$. J Food Sci. 1984;49:1350-4.

29. Aktas N, Genccelep H. Effect of starch type and its modifications on physicochemical properties of bologna-type sausage produced with sheep tail fat. Meat Sci. 2006;74:404-8.

30. Zhao Y, Hou Q, Zhuang X, Wang Y, Zhou G, Zhang W. Effect of regenerated cellulose fiber on the physicochemical properties and sensory characteristics of fat-reduced emulsified sausage. LWT Food Technol. 2018;97:157-63.

31. Rhodes VJ, Kiehl ER, Brady DE. Visual references for grades of retail beef cuts. Columbia, MO: University Of Missouri; 1955. Research Bulletin 583.

32. Ruusunen M, Vainionpaa J, Puolanne E, Lyly M, Lahteenmaki L, Niemisto M, et al. Physical and sensory properties of low-salt phosphate-free frankfurters composed with various ingredients. Meat Sci. 2003;63:9-16. 